\title{
Does Dust from Arctic Mines Affect Caribou Forage?
}

\author{
Wenjun Chen ${ }^{1}$, Sylvain G. Leblanc ${ }^{1}$, H. Peter White ${ }^{1}$, Christian Prevost ${ }^{1}$, Brian Milakovic ${ }^{2}$, \\ Christine Rock ${ }^{2}$, Greg Sharam², Harry 0'Keefe ${ }^{3}$, Laura Corey ${ }^{3}$, Bruno Croft ${ }^{4}$, Anne Gunn5, \\ Sjoerd van der Wielen ${ }^{6}$, Adeline Football' ${ }^{6}$, Boyan Tracz ${ }^{7}$, Jody Snortland Pellissey ${ }^{7}$, \\ John Boulanger ${ }^{8}$
}

${ }^{1}$ Canada Centre for Remote Sensing, Natural Resources Canada, Ottawa, Canada

${ }^{2}$ ERM Environmental Ressources Management, Vancouver, Canada

${ }^{3}$ Dominion Diamond Ekati Corporation, Yellowknife, Canada

${ }^{4}$ Environment and Natural Resources, GNWT, Yellowknife, Canada

${ }^{5}$ Circum Arctic Rangifer Monitoring and Assessment Network, Salt Spring Island, Canada

${ }^{6}$ Tlicho Government, Behchoko, NT, Canada

${ }^{7}$ Wek'èezhìi Renewable Resources Board, Yellowknife, Canada

${ }^{8}$ Integrated Ecological Research Ltd., Nelson, Canada

Email: Wenjun.Chen@Canada.ca

How to cite this paper: Chen, W.J., Leblanc, S.G., White, H.P., Prevost, C., Milakovic, B., Rock, C., Sharam, G., O'Keefe, H., Corey, L., Croft, B., Gunn, A., van der Wielen, S., Football, A., Tracz, B., Pellissey, J.S. and Boulanger, J. (2017) Does Dust from Arctic Mines Affect Caribou Forage? Journal of Environmental Protection, 8, 258-276. https://doi.org/10.4236/jep.2017.83020

Received: December 29, 2016

Accepted: March 13, 2017

Published: March 16, 2017

Copyright (c) 2017 by authors and Scientific Research Publishing Inc. This work is licensed under the Creative Commons Attribution International License (CC BY 4.0).

http://creativecommons.org/licenses/by/4.0/ (c) (i) Open Access

\begin{abstract}
This study explores how dust from the Ekati Diamond Mine potentially affects the availability and quality of forage on the seasonal range of the Bathurst caribou herd. Understanding the effects of dust as a source of disturbance is important because the Bathurst caribou population has declined by $93 \%$ since the middle 1980s and there are reports that caribou in general may avoid mining projects. There are several challenges for quantifying dust impacts: 1) Natural variations (e.g., topography, natural disturbance, and soil $\mathrm{pH}$ ) may also impact forage availability and quality for caribou. To minimize their masking effect, we stratified survey sites into seven land cover classes and selected the most populous class (i.e., the dwarf shrub) for assessing the impact. 2) Within class variation (e.g., the proportion of area covered by rocks where vascular plants and lichen do not grow) can further skew the analysis. We eliminated this problem by examining only the area not covered by rocks. 3) Coarse and fine suspended particulates have different spatial coverages, chemical compositions, and $\mathrm{pH}$ values. Consequently, their impacts on caribou forage can be different. To distinguish their impacts, we sampled two areas: transects from the Misery Haul Road that has been in active use vs. those from a rarely used spur road outside the Misery Camp. We sampled percent vegetation cover, soil $\mathrm{pH}$, and dust on leaves along these transects during the summers of 2015 and 2016. Our results indicated that the amount of dust on leaves in a zone of $\sim 1000 \mathrm{~m}$ from the Mis-
\end{abstract}


ery Haul Road was 3 - 9 times than that of background sites. The zone of reduced lichen percent cover was also about $1000 \mathrm{~m}$. In contrast, these road dustinduced changes in caribou forage were not observed for the dust-free transect from the spur road.

\section{Keywords}

Mining, Arctic, Caribou Habitat, Road Dust, $\mathrm{PM}_{2.5}$, Vegetation Cover, Lichen, Soil pH, Dust Deposition

\section{Introduction}

The population of the Bathurst barren ground caribou (Rangifer tarandus groenlandicus, hereafter described as "Bathurst Caribou") has declined 93\% since 1986 [1]. Declines have also been reported for other barren ground caribou and wild reindeer herds around the globe [2].

A combination of many natural and human factors (e.g., habitat, harvest, predators, diseases, parasites, insects, extreme weather, climate change, industrial development, and pollution) may have contributed to the decline [3] [4] [5]. Among these factors, climate change and an increase in industrial development have been notable across the Arctic in recent decades [6]-[12]. The climate in the Arctic has been changing at almost twice of the global average rate during the last century [6]. Under changing climate, the area of lichen-rich mature forest over the Bathurst Caribou winter range has decreased as the burned area increases with warmer summer temperatures [7]. The accessibility to lichen, the main diet of caribou during the winter, may have also been influenced by an increase in thaw-freeze events and ice content in snow [7]. On the summer range, the high variability of forage availability during the post-calving period and fall may result in a decrease in net caribou productivity, namely, the late-winter calf: cow ratio [8]. Also, a warming climate may prolong the duration of insect activity and thus negatively impact caribou energetics, health, and growth [9] [10].

There has been an increase in mining exploration, operation, and reclamation activities within the Bathurst Caribou range since the 1980s. Active mines include the Ekati Diamond Mine, Diavik Diamond Mine, Snap Lake Diamond Mine, and GahchoKue Diamond Mine [11] [12]. Also, there are several mining exploration projects, as well as reclamation projects for closed mines [11]. Traditional knowledge indicates that some of the potential effects of mining operations on caribou might include the shifting of caribou migration routes away from mining areas, and the deterioration of caribou health (e.g., abnormal material and smell in caribou meat, liver, and the hide linings) [13]. Boulanger et al. [14] estimated that there were fewer caribou with a zone of influence (ZOI) of about 14 km surrounding the Ekati-Diavik mining complex based on caribou aerial survey data and locations of satellite-collared cows.

However, little is known about the mechanisms that may produce a $\mathrm{ZOI}$. Ob- 
servations by local community members [13] suggested that the sight of, noise from, and road dust released by mining operationsmight influence caribou. In addition to road dust, other sources of airborne particulate matter may include diesel fuel combustion, living waste incineration, and the secondary chemical reactions in the atmosphere [15]. According to their sizes, particulate matter can be classified as fine particulate matter $\left(\mathrm{PM}_{2.5}\right.$ with aerodynamic diameter $\left.<2.5 \mu \mathrm{m}\right)$ and coarse particulate matter (aerodynamic diameter $\geq 2.5 \mu \mathrm{m}$ or the total suspended particulates diameter TSP- $\mathrm{PM}_{2.5}$ ) [15]. The concentrations of TSP and $\mathrm{PM}_{2.5}$ are usually monitored through air sampling [15]. Their deposition rates were also monitored at some locations. For example, the deposition rate of TSP (or dust deposition) was monitored at a number of locations around the Ekati Diamond Mine [16]. The depositions of both coarse and fine particulate matters might impact tundra ecosystem properties (e.g., soil $\mathrm{pH}$ ) as well as caribou forage quality and growth. In this study, our objective is to answer the question: how have the Ekati mining operations affected the availability and quality of forage for caribou?

\section{Materials and Methods}

\subsection{Study Area}

The Bathurst caribou herd ranges over a vast area from $63^{\circ} 50^{\prime} \mathrm{N}-66^{\circ} 27^{\prime} \mathrm{N}$ and $107^{\circ} 31^{\prime} \mathrm{W}$ - $114^{\circ} 43^{\prime} \mathrm{W}$ determined by locations obtained from satellite-collared cows from 1996 to 2012 [17]. Bathurst caribou calve to the west and southwest of Bathurst Inlet, winter below treeline in the Northwest Territories and the northern portion of Saskatchewan, and during the summer forage on tundra areas in between. The Ekati Diamond Mine is located in the middle the summer range of the Bathurst caribou herd (Figure 1).

Field surveys were conducted near the Ekati Diamond Mine during August 12-24, 2015, and August 15-29, 2016. The field surveys were conducted along six transects (Figure 1). Five of the transects (red lines) were along the active portion of the Misery Haul Road, indicated by $\mathrm{km}$ markers relative to the Main Camp and direction ( $3 \mathrm{~km}$ west, $5 \mathrm{~km}$ east, $8 \mathrm{~km}$ west, $20 \mathrm{~km}$ south, and $20.2 \mathrm{~km}$ south). Transects $20 \mathrm{~km}$ south and $20.2 \mathrm{~km}$ south are approximately $200 \mathrm{~m}$ apart, but their vegetation distributions were sufficiently different to be treated as two independent transects. One transect was sampled at the rarely used spur road outside the Misery Camp, and is shown in green in Figure 1.

\subsection{Field Survey Methods}

GPS position was measured using two Trimble NetR9 GNSS Reference Receivers coupled with Trimble antennas. These receivers are capable of recording both GPS and Glonass data. One receiver was set at a base station near a road and acquired data in static mode throughout the day. The other receiver and its antenna were placed in a backpack and carried along a transect for a total daily distance of several kms. Both receivers were acquiring data simultaneously at a1-second interval. Base station data were also acquired at a 30-second interval for processing by NRCan Precision Point Processing service. Post processing generated tens of 


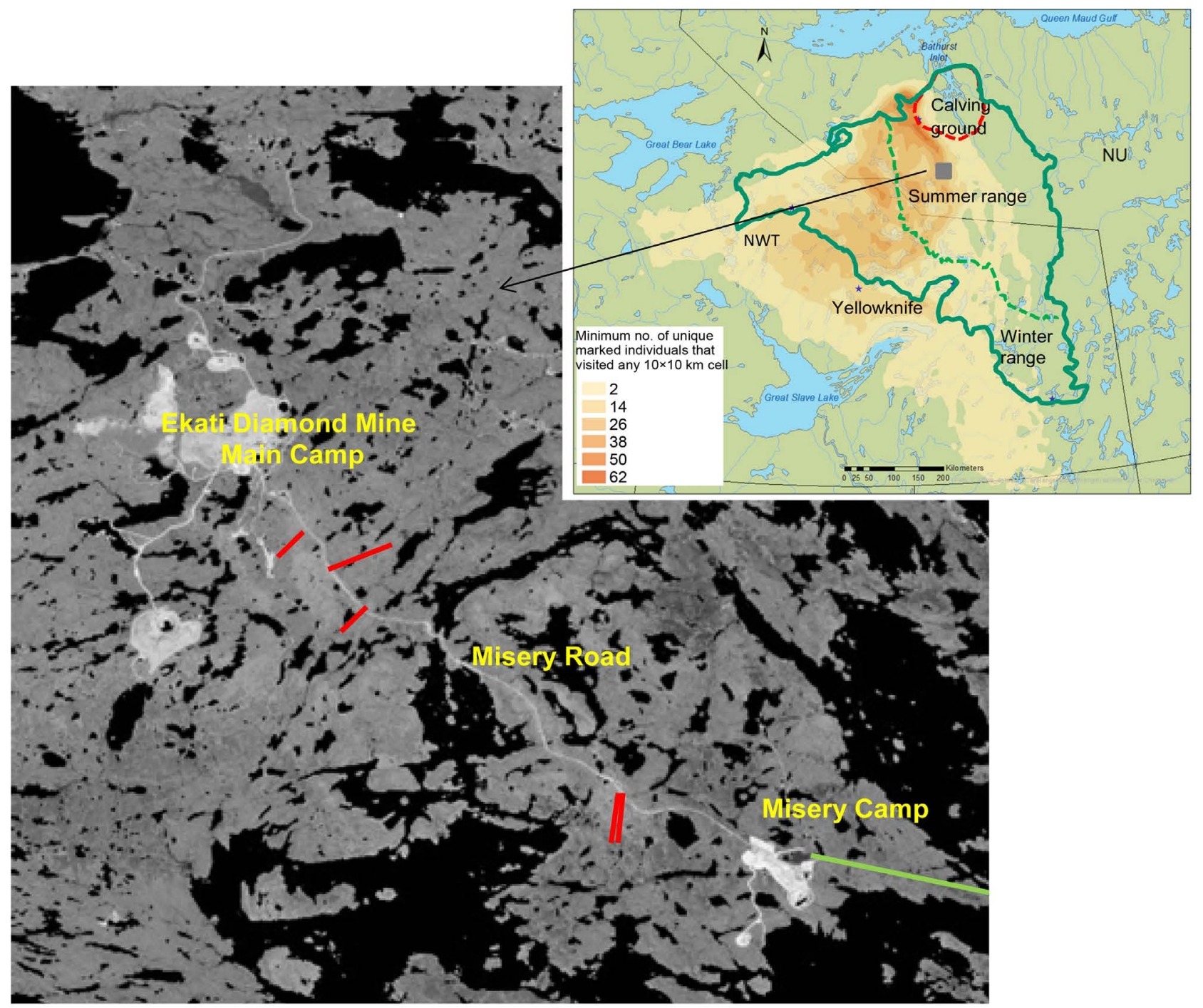

Figure 1. Location of vegetation field measurement transects (red and green lines) around the Ekati diamond mine inside the Bathurst caribou habitat, which is located in the bordering region of NWT, Nunavut, and Saskatchewan.

thousands of 3-dimensional points (i.e., latitude, longitude, and elevation). Planimetric results are in NAD 83 CSRS, while altimetry (orthometric) is in CGDV28.

Sampling sites were located at $0.1,5,10,30,100,200,300,500,750,1000$, $1250,1500 \mathrm{~m}$ along each transect. The percent cover for each vascular plant species, lichen, and moss, bare ground, and rock was visually estimated along each transect following methods described in [18]. The mean height of each vascular plant species was measured using a ruler for five representative plants per site. Down-looking digital photos with regular visible bands were then taken. These down-looking photos provide a more reliable estimate of percent cover [19], and were used to correct any potential observer bias. Down-looking NDVI photos with the near-infrared band and visible bands were also taken at select sites. Leblanc et al. [20] have developed a method to derive surface reflectance information from digital photos, which can be used to better link field measurements with satellite remote sensing imagery and to assess if remote sensing can detect 
dust accumulation on leaves.

Dwarf birch (Betula nana) was the most common plant species at all these sites and was selected as an indicator species for quantifying potential effects of dust from mining operations on the quality of caribou forage. Leaves from dwarf birch were collected at each site and the amount of dust present on leaves was analyzed at the Environment Laboratory of the Ekati Diamond Mine.

The soil sample was collected from each site to determine soil $\mathrm{pH}$. The top 0 to $5 \mathrm{~cm}$ of soil is considered the layer most affected by airborne contaminants such as dust, and thus is the layer of most interest for both human and wildlife health risk assessments [21]. We collected a 50 to $100 \mathrm{~g}$ soil sample from the top $5 \mathrm{~cm}$ of the soil layer, and near the dominant plant species at the site, which was usually dwarf birch. The sample was taken back (in a paper bag if the sample was relatively dry or a plastic Ziplock bag if the sample was wet) to the Environment Laboratory of the Ekati Diamond Mine to analyze soil $\mathrm{pH}$.

\subsection{Laboratory Methods}

To measure the amount of dust on dwarf birch leaves in the laboratory, we weighed about 1 gram of air-dried leaves from a site and submerged them into $100 \mathrm{ml}$ of distilled water. The leaves were well stirred and left in the water for 10 minutes to allow the dust to dissolve into the water. Three $10 \mathrm{ml}$ samples of the water were used to measure the turbidity of the solution using an EPA compliant

(http://www.coleparmer.ca/) LaMotte LTC3000we Benchtop Turbidity and Chlorine Meter. Results are in Nephelometric Turbidity Units (NTU) per $100 \mathrm{ml}$ water per gram of air-dry leaves.

Soil $\mathrm{pH}$ was measured using a soil $\mathrm{pH}$ meter (HACH H135 Advanced Compact Water PR by Cole-Parmer Canada, http://www.hach.com/, or YSI Professional Plus Multiparameter Water Quality Instrument, https://www.ysi.com/proplus). The analysis followed these steps:

- A batch of 8 to 10 beakers $(300 \mathrm{ml})$ was washed using distilled water.

- Approximately $10-20 \mathrm{~g}$ of a soil sample from a site was added to a beaker.

- Distilled water was added to the beaker to fully cover the soil sample.

- The solution was shaken and then allowed to settle for approximately 5 minutes.

- A digital photo of the solution was taken, together with a site label.

- The $\mathrm{pH}$ meter calibrated with standard solutions at $\mathrm{pH}=4,7$, and 10.

- The $\mathrm{pH}$ meter was then washed with distilled water after calibration and shaken dry.

- The soil solution was transferred to a $50 \mathrm{ml}$ beaker, and the $\mathrm{pH}$ meter was submerged into it and allowed to stabilize (usually $<5$ minutes). The $\mathrm{pH}$ value for the site was then recorded.

- The above steps were repeated so that 5 soil $\mathrm{pH}$ measurements were conducted for each site.

\subsection{Data Analysis Methods}

To quantify the impacts of mining related dust on caribou forage, we had to over- 
come a number of challenges. First is the large natural variation in the availability of caribou forage caused by numerous factors that could mask the effects of mine related dust deposition. For example, Gould and Walker [22] reported that distribution and richness of vegetation along the Hood River might vary greatly due to influences of topography, disturbance, and soil $\mathrm{pH}$. The Hood River is located at the northern extent of the Bathurst caribou range and has not been subject to industrial development. In this study, we stratified all sites into seven land cover classes: boulder field, esker, lichen-rock tundra, dwarf shrub, low-tall shrub, tussock, and graminoid wetland. Within a given land cover class; differences associated with topography, disturbance, and soil $\mathrm{pH}$ tend to be reduced. Therefore, we could minimize the natural variation byanalyzing the impacts of mining related dust on caribou forage within a particular land cover class. Only the dwarf shrub class had a sufficient sample size for statistical analysis.

The second challenge is the remaining within-class natural variation, particularly in the extent of \% rock cover. Vascular plants and lichen that caribou feed on do not grow on the bare surface of rocks. As a result, variation in the amount of rock cover between dwarf shrub sites could significantly bias the results. We addressed this challenge by removing the rock fraction in a site from the analysis and the percent cover of a given plant species is calculated for the remaining area:

$$
\text { Corrected } \% \text { cover }=\text { surveyed } \% \text { cover } \times 100 /(100-\text { rock } \% \text { cover }) .
$$

The third challenge is that coarse and fine particulate matter released from mining operations may impact caribou forage differently [15]. The coarse particulate matter is mechanically produced by the break-up of larger materials. For the surrounding area around the Ekati Diamond Mine, dust is mainly from traffic on unpaved roads constructed using crushed granite or wind-blown over the uncovered soil. The dominant components of granite are silicon ( $72 \%$ weight), aluminium (14\%), potassium (4\%), sodium (4\%), iron (3\%), calcium $(2 \%)$, and magnesium (1\%) [23]. Metal analysis of dust samples collected from dust deposition stations near the haul roads during 2012-2014 show similar results. The major metal components of dust were aluminum (8\%), potassium (6\%), sodium (2\%), calcium (4\%), and magnesium ( $8 \%$ ) besides $72 \%$ silicon [16]. Silicon dioxide and aluminum oxide are not water soluble under natural environment conditions and thus neutral in $\mathrm{pH}$. The $\mathrm{pH}$ values of other metal solutions in water (e.g., potassium hydroxide) and their carbonated compounds (e.g., potassium carbonate, potassium hydrogen carbonate) range from 8 to 12

(http://www.aqion.de/site/191). Consequently, a typical $\mathrm{pH}$ value of road dust from a haul road is expected to be about 9. At the Ekati Diamond Mine, road dust suppression agents have been applied on the Misery Haul Road in recently years. The $\mathrm{pH}$ values of road dust suppression agents are typically acidic. As a result, the $\mathrm{pH}$ of dust from the Misery Haul Road may vary tempo-spatially depending on the amount, timing, and types of dust suppression agents applied.

$\mathrm{PM}_{2.5}$ contains most of the emissions from fossil fuel combustion, secondary particulates, biomass burn, and the finer components of road dust [23]. The se- 
condary particulates are produced by the chemical reactions in the atmosphere. For example, sulfur dioxide is oxidized in the atmosphere to form sulfuric acid $\left(\mathrm{H}_{2} \mathrm{SO}_{4}\right)$. Nitrogen dioxide $\left(\mathrm{NO}_{2}\right)$ is oxidized to nitric acid $\left(\mathrm{HNO}_{3}\right)$, which in turn reacts with ammonia $\left(\mathrm{NH}_{3}\right)$ to form ammonium nitrate $\left(\mathrm{NH}_{4} \mathrm{NO}_{3}\right)$. The compositions of $\mathrm{PM}_{2.5}$ at the Edmonton McIntyre Air Monitoring Station in 2007 were measured to be organic carbon ( $45 \%$ weight), elemental carbon (15\%), sulfur dioxide (17\%), nitrate (9\%), and Ammonium (10\%) [24]. The corresponding acids (i.e., sulfuric acid, nitric acid, and carbon acid) have $\mathrm{pH}$ values ranging from 1 to 4, comparable with the finding that the $\mathrm{pH}$ values of $\mathrm{PM}_{2.5}$ are usually $<3$ [25].

Because of their larger particulate sizes, road dust tends to deposit onto the land surface within a shorter distance and timeframe, relative to $\mathrm{PM}_{2.5}$. With different $\mathrm{pH}$ values, they can also affect soil $\mathrm{pH}$ differently. Regarding direct impacts on vegetation beside the change of soil $\mathrm{pH}$, an acidic $\mathrm{PM}_{2.5}$ solution containing heavy metals may result in a decrease in lichen survival rate [26]. On the other hand, road dust may affect vegetation photosynthesis, respiration, transpiration when dust covers a leaf surface [27]. In this study, we addressed this challenge by investigating two contrasting transects, namely, those from a haul road vs. those largely dust-free from a rarely used spur road.

\section{Results}

\subsection{Topography, Disturbance, and Land Cover Classes}

The topography surrounding the Ekati Diamond Mine is a gently rolling landscape. Along the survey transects, elevation typically varied less than $20 \mathrm{~m}$ within $2.5 \mathrm{~km}$ of the mine (Figure 2).

Lichen-rock tundra class was found on the tops of hills at some sites. Hill tops tend to be drier than slopes or down in the valley (Table 1). The wettest sites are usually located at valley bottoms, where graminoid wetland, tussock, and lowhigh shrub classes are typically found. The dwarf shrub class occupies most of the slope sites, as well as some of the sites at the hilltop and valley bottoms. Two other classes (boulder field and esker) represent the legacy of glaciation and deglaciation processes in this region [28]. Dominated by coarse materials such as boulders, gravels, and sands, these classes are driest in terms of moisture regime (Table 1). Among all sites sampled along the six transects, dwarf shrub was the most prevalent class ( $81 \%)$, followed by esker (5\%), and the low-high shrub and tussock classes (4\% each). As a result, the dwarf shrub class was selected as an appropriate indicator for the potential effects of mine related dust on caribou forage.

\subsection{The Amount of Dust on Leaves}

The amount of dust per gram of air-dried dwarf birch leaves decreased with distance from the Misery Haul Road (Figure 3); however, there was substantial variation between transects. For the majority of transects from the Misery Haul Road, the highest amount of dust on leaves was recorded for sites closest to the road. Some exceptions may occur. For example, the highest amount of dust on 


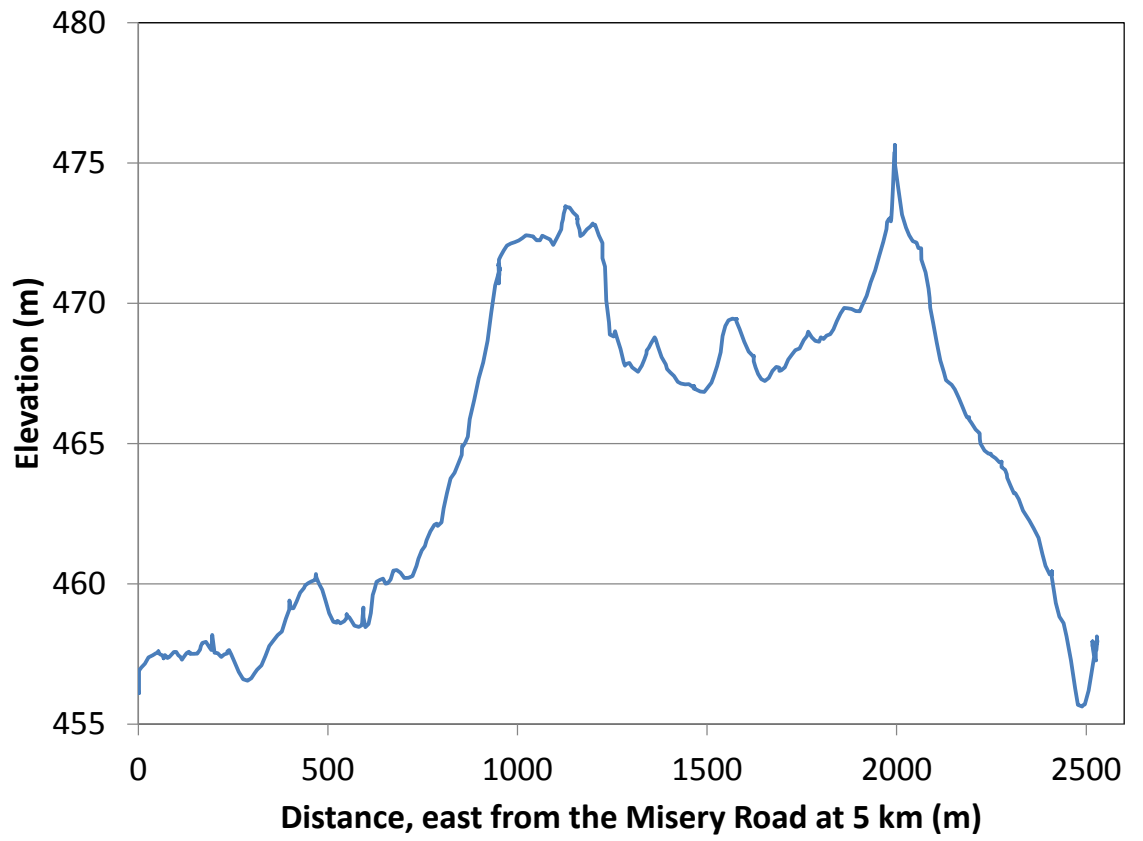

Figure 2. Elevation change on the east transect from the misery haul road at $5 \mathrm{~km}$ benchmark from the main camp, based on the precision GPS survey on August 19, 2016.

Table 1. Description of land cover classes over the area surrounding the Ekati diamond mine.

\begin{tabular}{|c|c|c|c|c|}
\hline $\begin{array}{l}\text { Land cover } \\
\text { class }\end{array}$ & Description & Topography & Disturbance & $\begin{array}{l}\% \text { of } \\
\text { sites }\end{array}$ \\
\hline Boulder field & Boulders, xeric & Flat area & Deglaciation & 2 \\
\hline Esker & Sands, gravels, xeric & Flat area & Deglaciation & 5 \\
\hline $\begin{array}{l}\text { Lichen-rock } \\
\text { tundra }\end{array}$ & $\begin{array}{l}\text { Lichen, bare surface, dwarf } \\
\text { shrub, xeric to subxeric }\end{array}$ & Hill top & $\mathrm{n} / \mathrm{a}$ & 1 \\
\hline Dwarf shrub & dwarf shrub, subxeric to mesic & Slopes & $\mathrm{n} / \mathrm{a}$ & 81 \\
\hline $\begin{array}{l}\text { Low-high } \\
\text { shrub }\end{array}$ & $\begin{array}{c}\text { Shrubs }>50 \mathrm{~cm} \text { high, mesic to } \\
\text { subhygric }\end{array}$ & Valley & $\mathrm{n} / \mathrm{a}$ & 4 \\
\hline Tussock & Tussocks, mesic to subhygric & Valley & $\mathrm{n} / \mathrm{a}$ & 4 \\
\hline $\begin{array}{l}\text { Graminoids } \\
\text { wetland }\end{array}$ & Graminoids, Subhygric to hygric & Valley & $\mathrm{n} / \mathrm{a}$ & 3 \\
\hline
\end{tabular}

leaves collected from the $8 \mathrm{~km}$ west transect was found at $100 \mathrm{~m}$, indicating the high special variability in the measurements of dust on leaves. In contrast, the highest dust deposition was always observed by the Ekati Diamond Mine [16].

In addition to topography and winds, rain events may further affect the amount of dust on leaves. Our in-situ observations suggest that traffic can stir dust from an unpaved road within 12 hours after a rain event. The longer the duration after a rain event, the higher the amount of dust may be stirred up by traffic. All surveys were conducted after rain events of differing intensity and durations, and the amount of dust on leaves represents an accumulation of dust deposition after a rain event. With high variability in topography, wind direction and speed, rain 


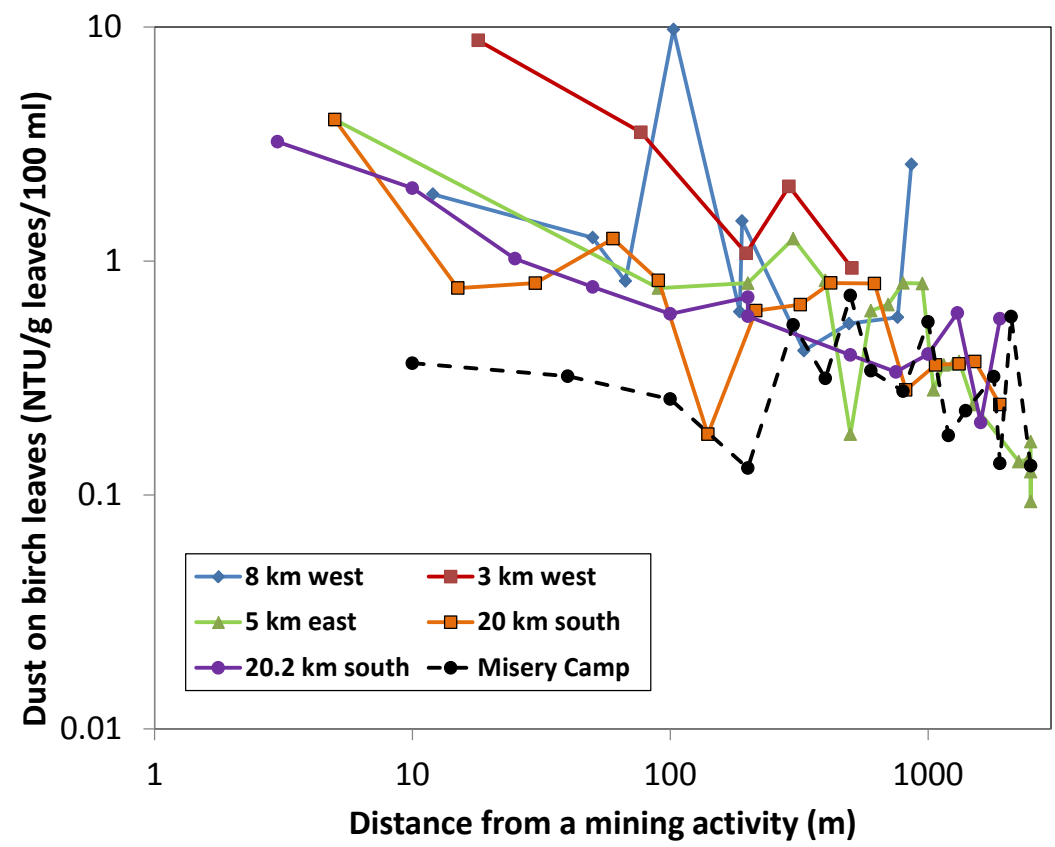

Figure 3. The amount of dust on leaves of dwarf birch plotted against the distance from the misery haul road ( $3 \mathrm{~km}$ west, $8 \mathrm{~km}$ west, $5 \mathrm{~km}$ east, $20 \mathrm{~km}$ south, and $20.2 \mathrm{~km}$ south), as well as from a rarely used end road outside of the misery camp.

intensity, and the time interval between rain events and the field survey, a single measurement of dust on leaves may be less meaningful. With this in mind, we averaged the amount of dust on leaves over a range of distances along all transects from the Misery Haul Road (Table 2).

The average amount of dust on leaves at sites within $10 \mathrm{~m}$ was $8.8 \pm 2.2$ times higher than at sites $>1500 \mathrm{~m}$ from the Misery Haul Road (Table 2). A significantly higher amount of dust was recorded from leaves collected from $>500 \mathrm{~m}$ to $1000 \mathrm{~m}$, which was $2.6 \pm 0.9$ times higher than leaves collected from sites $>1500 \mathrm{~m}$ from the Misery Haul Road. However, there was no statistically significant difference in the amount of dust from leaves collected from $>1000$ to $1500 \mathrm{~m}$ and from $>1500$ $\mathrm{m}$, indicating the maximum distance of higher than background amount of dust on leaves was about $1000 \mathrm{~m}$. Our finding is comparable with the direct dust deposition monitoring results [16].

In contrast, there was no significant difference in the amounts of dust among sites on the transect from a rarely used spur road outside of the Misery Camp (Figure 3 and Table 2). This result confirms our finding that the amount of dust on leaves at sites within $1000 \mathrm{~m}$ of the Misery Haul Road was significantly higher than background level.

\subsection{Impacts on Soil pH}

The average $\mathrm{pH}$ value of dust samples taken from transects along the Misery Haul Road was $8.63 \pm 0.44$, ranging from 8.1 to 9.4 (Figure 4). The variation in dust $\mathrm{pH}$ values may be related to differences in the application of dust suppressing 
Table 2. The ratio of the amount of dust on leaves averaged over sites within a given distance range to that $>1500 \mathrm{~m}$ (a) from the Misery Haul Road, as well as (b) from a rarely used end road outside of the Misery Camp. The error values are one standard estimation error relative to the mean dust amount for sites $>1500 \mathrm{~m}$.

\begin{tabular}{ccc}
\hline & \multicolumn{2}{c}{ Ratio of dust on leaves } \\
\cline { 2 - 3 } $\begin{array}{c}\text { Distance range } \\
\text { Boulder field (m) }\end{array}$ & $\begin{array}{c}\text { From the Misery Haul } \\
\text { Road }\end{array}$ & $\begin{array}{c}\text { From a rarely used end road outside } \\
\text { the Misery Camp }\end{array}$ \\
\hline 10 & $8.8 \pm 2.2$ & $1.3 \pm 0.4$ \\
$>10-100$ & $6.1 \pm 2.3$ & $1.0 \pm 0.4$ \\
$>100-500$ & $4.2 \pm 1.9$ & $1.4 \pm 0.6$ \\
$>500-1000$ & $2.6 \pm 0.9$ & $1.3 \pm 0.5$ \\
$>1000-1500$ & $1.1 \pm 0.4$ & $0.7 \pm 0.4$ \\
\hline
\end{tabular}

agents, construction material, and usage history. The area with the heaviest application of dust suppression agents is the airstrip. The $\mathrm{pH}$ value of samples collected from the airstrip was $6.1 \pm 0.2$, while the $\mathrm{pH}$ values for dust sampled from haul roads with no application of dust suppression agents ranged from 9 to 10. The variation in $\mathrm{pH}$ values for the dust samples collected from transects along the Misery Haul Road fell between the air strip and haul road without dust suppression, and likely related to the difference in the amount, timing, and types of dust suppression agents applied.

The $\mathrm{pH}$ values of dust were much higher than those of tundra soils not disturbed by natural erosion or affected by dust deposition, typically ranging from 4 to 6 [22]. The large difference in $\mathrm{pH}$ values between road dust and tundra soils suggests that there should be a gradient in soil $\mathrm{pH}$ from basic to acidic $\mathrm{pH}$ values as the distance from the haul road increases. A significant relationship between the soil $\mathrm{pH}$ and the distance from the Misery Haul Road was observed (Figure 5). Soil $\mathrm{pH}$ decreased logarithmically from about 9 at the roadside to about 4.5 at a distance around $1000-1500 \mathrm{~m}$, beyond this distance, the soil $\mathrm{pH}$ fluctuated around 4.5 .

In contrast, a decrease in soil $\mathrm{pH}$ with distance was not observed along the transect from a rarely used spur road outside the Misery Camp (Figure 6). In fact, we found a significantly increasing trend with distance for this transect. Simulation results from a CALPUFF air dispersion model show that the concentration of $\mathrm{PM}_{2.5}$ tends to be higher at sites close to mining operations [14], resulting in decreased soil $\mathrm{pH}$ at these sites. As such, the increasing trend with distance for this transect could be explained by the influence of $\mathrm{PM}_{2.5}$, which has a $\mathrm{pH}<3$ [25]. However, we noticed that the difference in $\mathrm{pH}$ values between $\mathrm{PM}_{2.5}$ and natural tundra soil was significantly less than that between road dust and natural tundra soil of the dwarf shrub class. In addition, the concentration of coarse particulates (TSP- $\mathrm{PM}_{2.5}$ ) tends to be much higher than that of $\mathrm{PM}_{2.5}$ [16]. As a result, the impact of coarse particulates was found to be more dominant than that of $\mathrm{PM}_{2.5}$. Nevertheless, the two contrasting trends are indicative of the different impacts of 


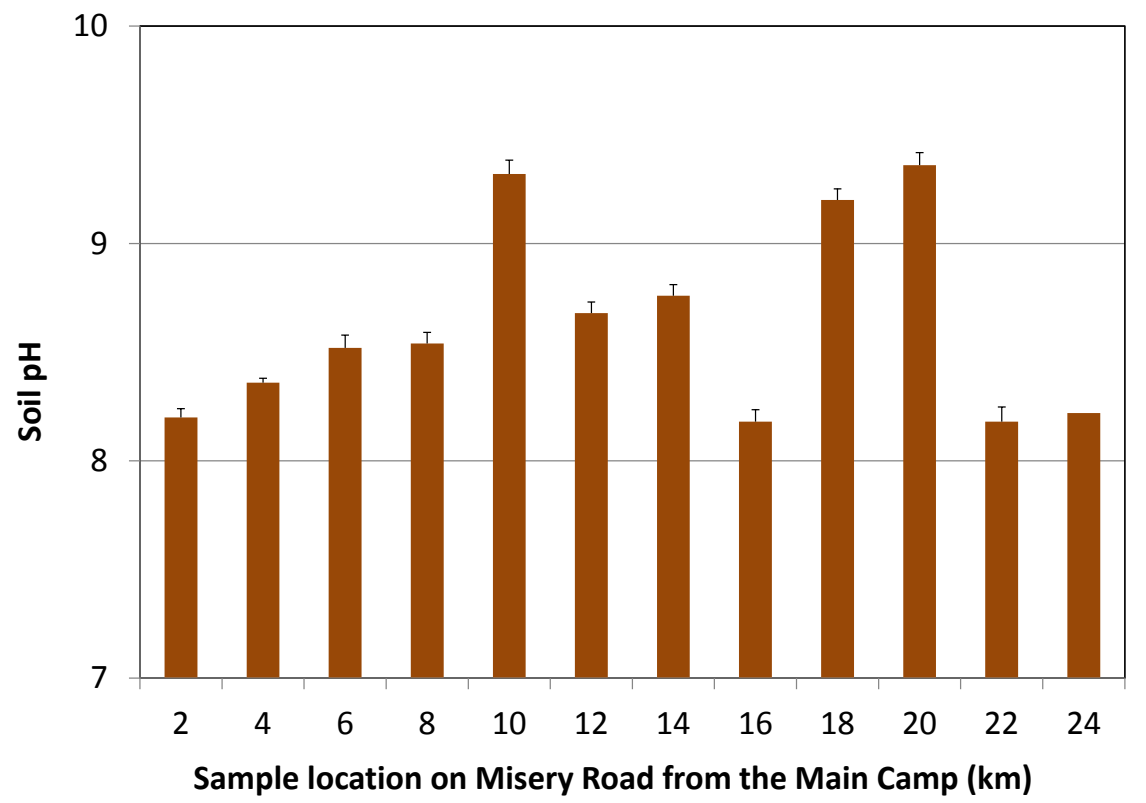

Figure 4. $\mathrm{pH}$ value of dust samples collected at roadside every $2 \mathrm{~km}$ along the misery haul road on August 20, 2015.

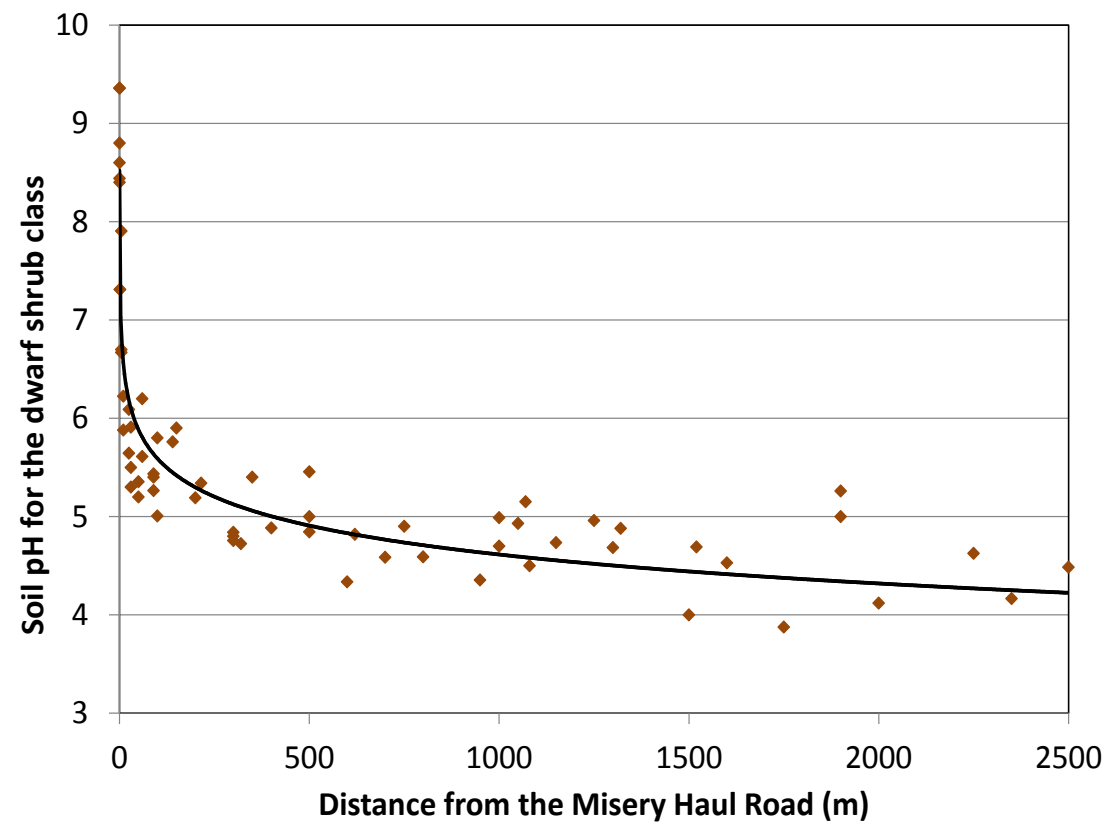

Figure 5. Soil $\mathrm{pH}$ change along the distance from the misery haul road, with the fit line given by $y=-0.424 \ln (x)+7.5446, R^{2}=0.90$, p-value $<0.01$, and the sample size $n$ $=65$. The $\mathrm{p}$-value was computed between measured and estimated $\mathrm{pH}$ values.

coarse particulates from road dust and $\mathrm{PM}_{2.5}$ on soil $\mathrm{pH}$.

\subsection{Relationships between Soil pH and Vegetation \% Cover}

We observed a significant $2^{\text {nd }}$ order polynomial relationship between the percent cover of vascular plants and soil $\mathrm{pH}$ (Figure 7). The optimum soil $\mathrm{pH}$ values for vascular plants were found to range from 4.5 to 6 . As soil $\mathrm{pH}$ increased above 6 , 


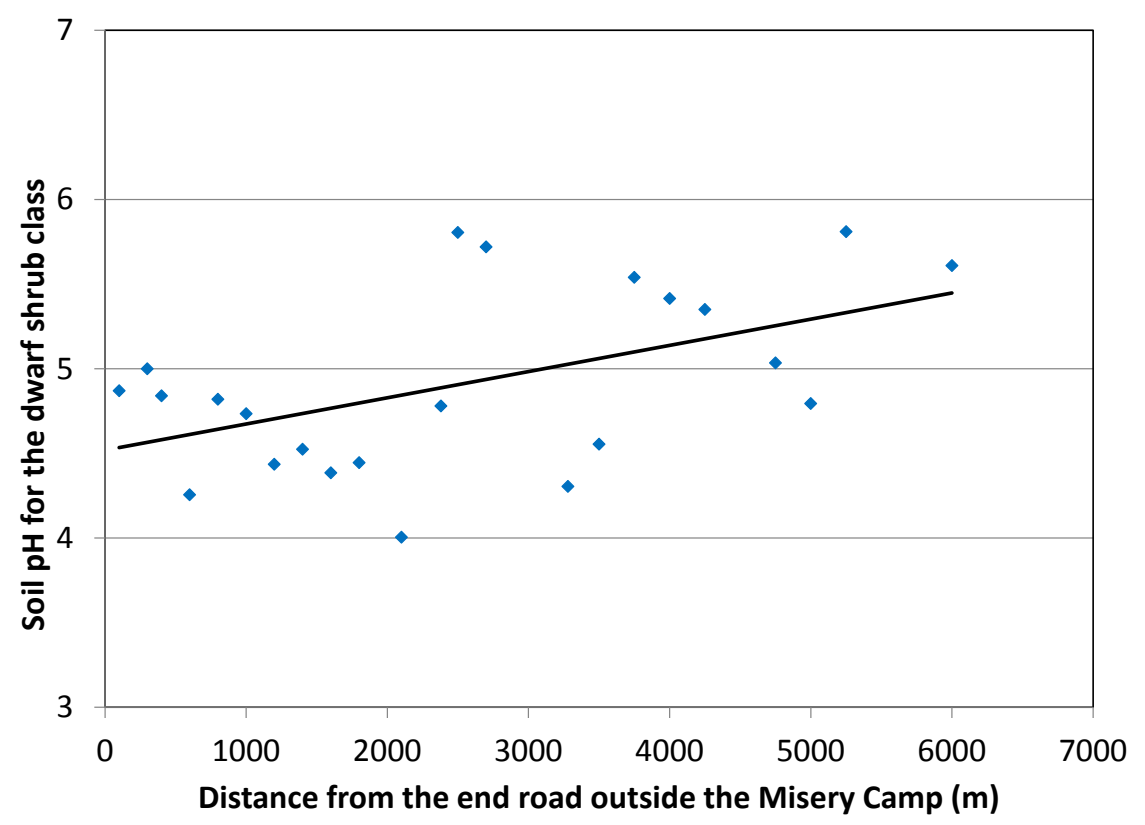

Figure 6. Soil $\mathrm{pH}$ change with distance for the transect from a rarely used end road outside of the misery camp, with the fit line given by $y=0.00015 x+4.5197, R^{2}=0.26$, pvalue $<0.05$, and the sample size $n=23$.

a significant reduction in the percent cover of vascular plants was observed.

In contrast, lichen was observed to prefer acidic soil (Figure 8). As soil $\mathrm{pH}$ increased from 4 to 9 , the percent cover of lichen decreased.

\subsection{Impacts on Vegetation Percentage Cover}

A significant reduction in vascular plant percent cover occurred within the first $10 \mathrm{~m}$ from the Misery Haul Road (Figure 9). This reduction corresponds to soil $\mathrm{pH}$ values $>6$ at sites near the Misery Haul Road (Figure 5). In addition, the amount of dust on leaves in this zone near the road is about nine times above background levels, which can contribute to a reduction in photosynthesis rates at these nearby sites and result in poor growth near the road.

There were no changes in the percent cover of vascular plants with distance from the Misery Haul road beyond the first $10 \mathrm{~m}$. The same can be said for the transect at the rarely used spur road outside of the Misery Camp. This result is expected given soil $\mathrm{pH}$ values beyond the first $10 \mathrm{~m}$ were generally in the range of $4.5-6$, the optimum soil $\mathrm{pH}$ range for the growth of arctic vascular plants (Figure 7). The higher amount of dust on leaves could potentially be negative for vascular plants but appeared to be masked by the large natural variation in vascular plant cover among sites.

Lichen distribution tends to be more sensitive to dust deposition. A significant reduction in the percent cover of lichen was observed at sites near the Misery Haul Road (Figure 10). The reduction in lichen cover corresponds to increased soil $\mathrm{pH}$ at sites within $1000 \mathrm{~m}$ of the Misery Haul Road and is indicative of the potential negative association between raised soil $\mathrm{pH}$ and lichen cover. 


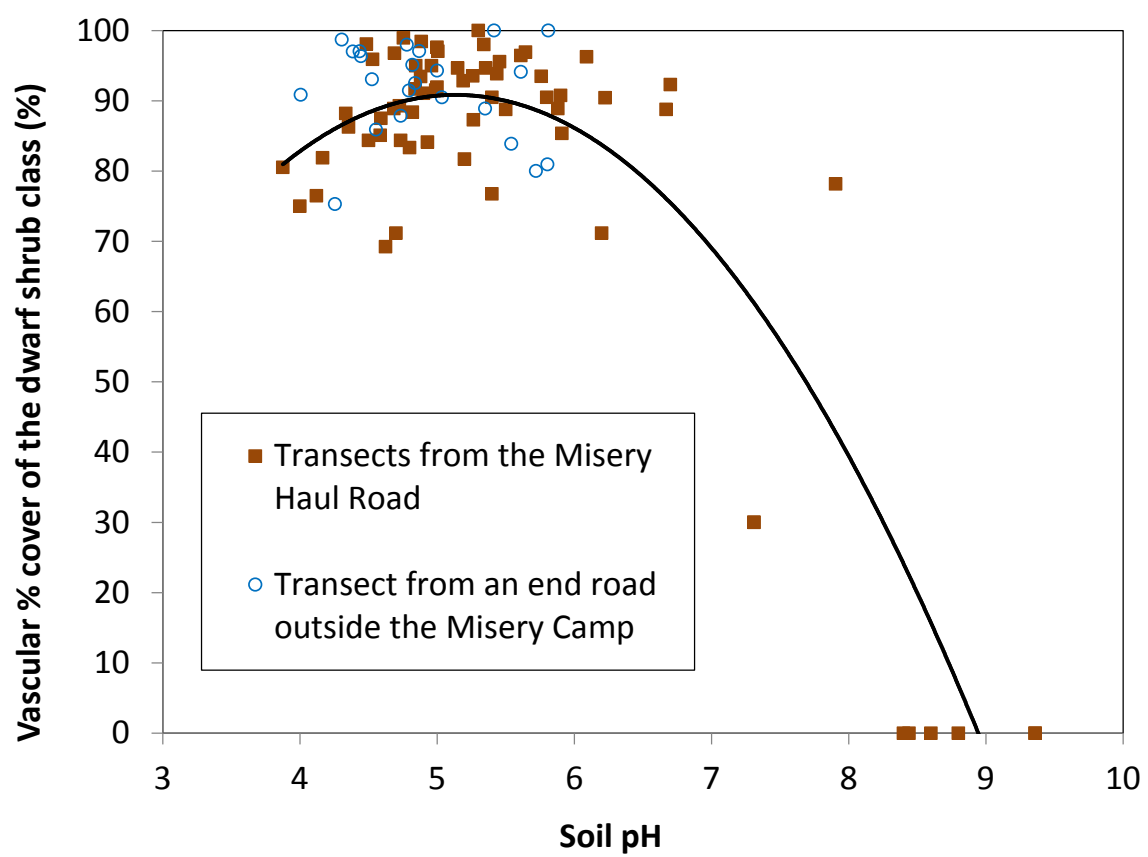

Figure 7. Relationship between soil $\mathrm{pH}$ and vascular plant \% cover for the transects from the Misery Haul Road, with the fit line given by $y=-6.2513 x^{2}+64.172 x-73.851, R^{2}=$ 0.84 , p-value $<0.01$, and the sample size $n=65$. The p-value was computed between measured and estimated vascular \% cover. Results for the transectfrom a rarely used spur road outside the misery camp were also plotted.

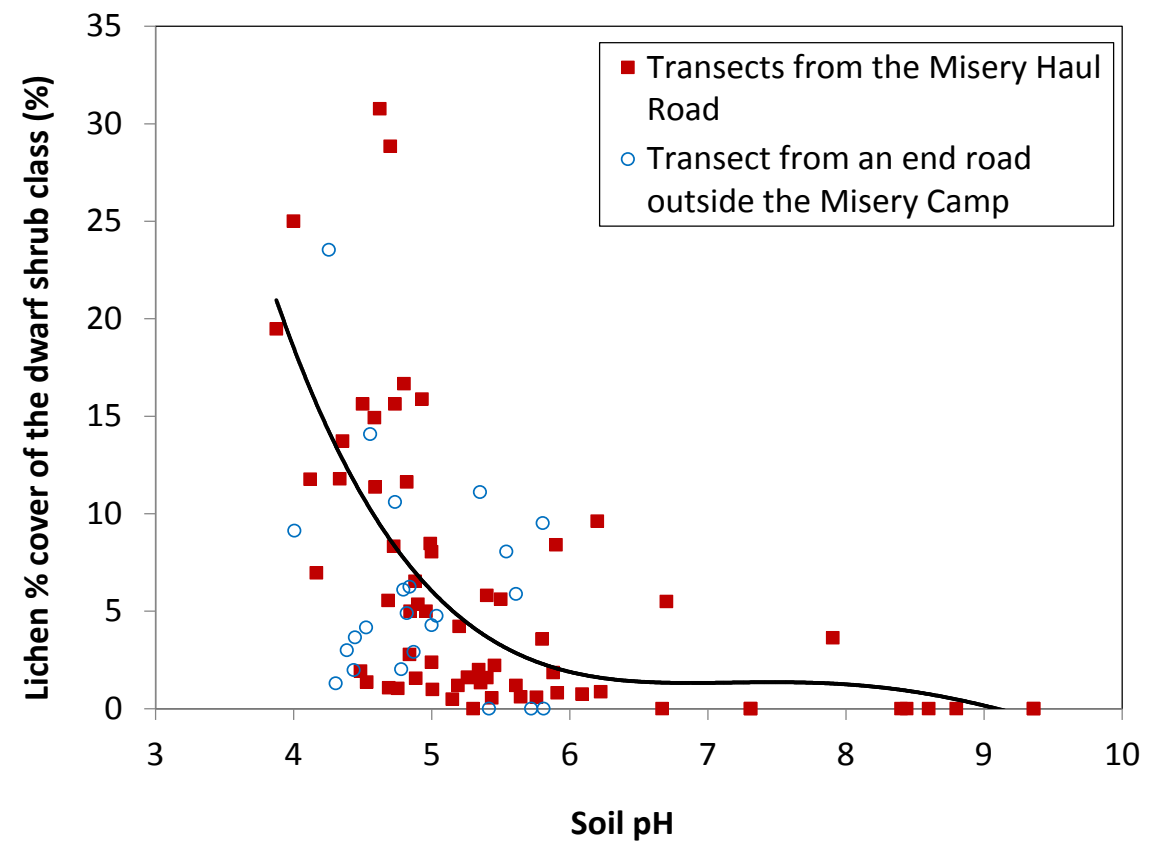

Figure 8. Relationship between soil $\mathrm{pH}$ and lichen \% cover for the transects from the Misery Haul Road, given by $y=0.0672 x^{4}-2.2663 x^{3}+28 x^{2}-151.03 x+302.49, R^{2}=0.41$, p-value $<0.01$, and $n=65$. The p-value was computed between measured and estimated lichen \% cover. Results for the transectfrom a rarely used end road outside the misery campwere also plotted.

For the transect from the rarely used spur road outside of the Misery Camp, 
no significant trend in the percent cover of lichen with distance was observed (Figure 10). If soil $\mathrm{pH}$ were the sole factor controlling the distribution of lichen, we would have expected a higher lichen $\%$ cover at sites near the spur road than those at $>2.5 \mathrm{~km}$ (Figure 6 and Figure 8). The fact no such an increase in lichen \% cover was observed suggests that the $\mathrm{PM}_{2.5}$ deposition may have some

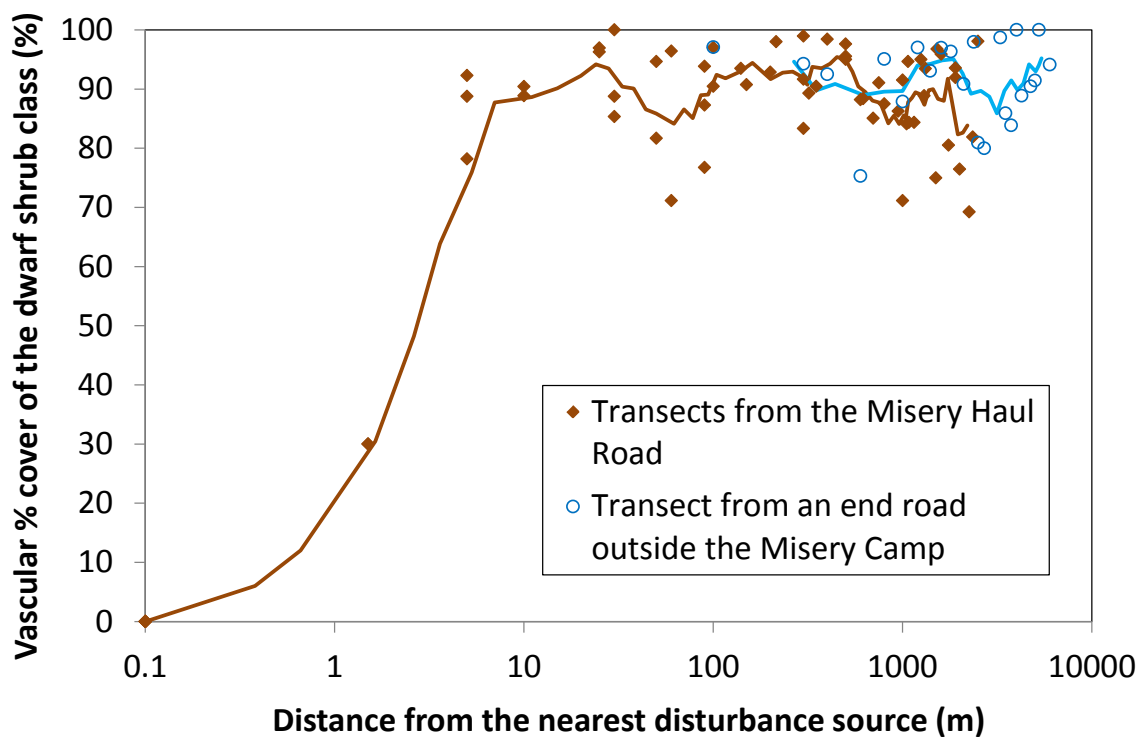

Figure 9. Vascular \% cover changes with distance for the transects from the misery haul road. Results for the transect from a rarely used end road outside of the misery camp were also plotted. The lines show the 5-point running mean.

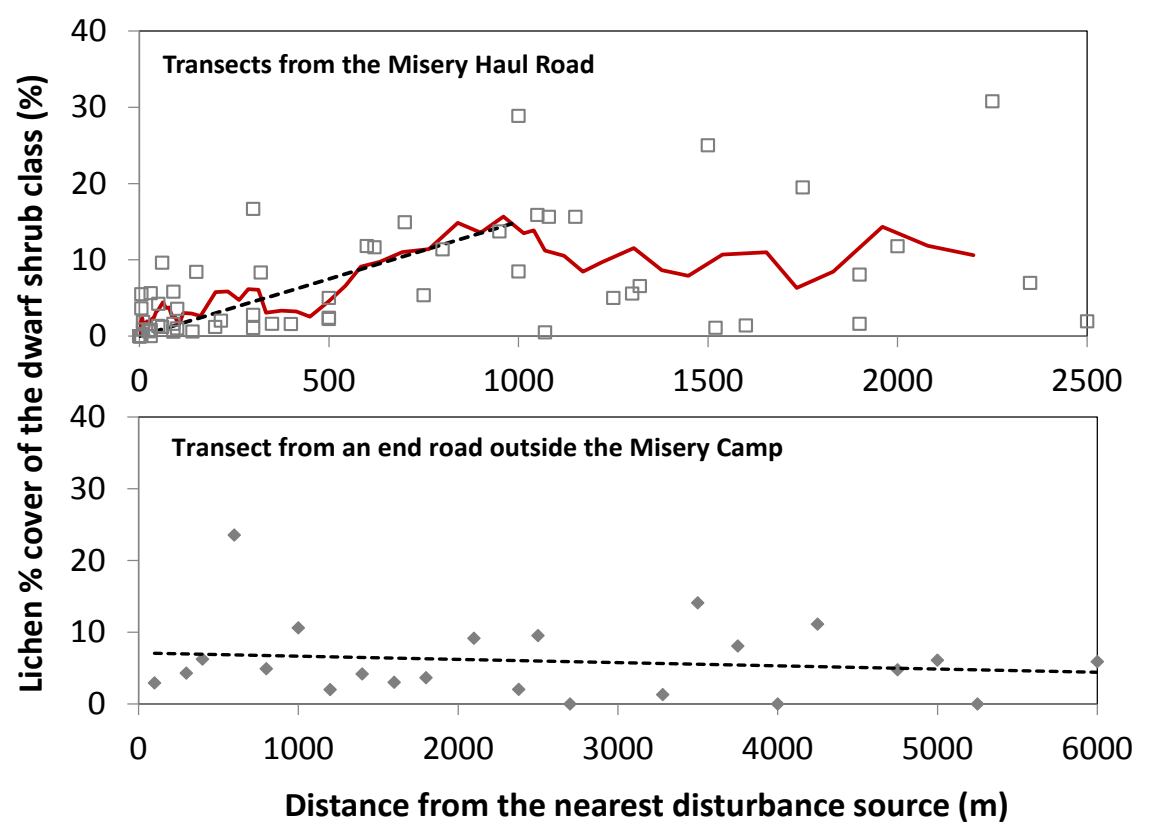

Figure 10. Lichen \% cover changes with distance from a mining operation. The red line shows the 5-point running mean, while dashed lines for linear trends: $y=0.0137 x+$ $1.0609, R^{2}=0.5075$, p-value $<0.01$, and $n=48$ for the first $1000 \mathrm{~m}$ from the Misery Haul Road; and $y=-0.0005 x+7.1191, R^{2}=0.02$, p-value $=0.5$, and $n=23$ for the transect from a rarely used end road outside of the misery camp. 
negative impact on lichen survival [26], and thus partially canceled out the potential positive effect of soil $\mathrm{pH}$ decrease on lichen cover near the Misery Camp.

\section{Discussion}

\subsection{Uncertainties in Field Survey Data}

The analysis of dust content on leaves may be subject to several error sources. For example, when we picked the leaves from plants in the field, some of the dust may be shaken off. Alternatively, if we would cut a branch or twigs in the field with minimal disturbance, we still had to pick out leaves in the laboratory for turbidity analysis and lose some dust in the process. More dust may be lost during transport from the field to the laboratory, during the air-drying process, and when the leaf sample was weighed and used for turbidity measurement. Also, the time since last rainfall may not have been equal for all sites. Finally, it is possible that dust on leaves may not be completely dissolved in the water solution during the turbidity measurement procedure. Consequently, the amount of dust on leaves quantified by the turbidity measurement method will not give us the absolute amount of dust on leaves. Instead, they should be used as a relative indicator of the amount of dust on leaves.

Similarly, the analysis of soil $\mathrm{pH}$ may also subject to errors. One of the main uncertainties in soil $\mathrm{pH}$ results is the possible variation in the soil depth from which soil samples were collected. Soil from naturally disturbed sites may also have a high $\mathrm{pH}$ value [20]. If a soil sample was collected at a deeper layer, we might find a higher soil $\mathrm{pH}$. We attempted to collect soil samples in the top 5 $\mathrm{cm}$; however, the actual depth from which the soil sample was collected may vary from site to site, and contribute to the variability in soil $\mathrm{pH}$ between sites. Another potential error may occur during the measurement of soil $\mathrm{pH}$. The $\mathrm{pH}$ meters we used were calibrated and accurate to within $0.1 \mathrm{pH}$ value. Uncertainty in the $\mathrm{pH}$ value may occur if dust in the water solution settled down to the bottom. Maintaining the soil solution by gently stirring the mixture during the measurement is recommended.

The percent cover of vascular plants and lichen was visually estimated in the field and later corrected using digital site photos [17]. While visual estimation is subjective, the digital photo analysis method is more accurate and provides some verification of field results. The digital photo analysis method can be time-consuming and can introduce additional error if there are overlaps between different vegetation types. Trends and means derived from these site measurements may be more reliable.

\subsection{Comparability with Previous Studies}

The significant influence of soil $\mathrm{pH}$ on the distribution of vascular plants and lichen was also reported by the Hood River study [22]. Despite the difference in vegetation parameters used in the two studies (species richness in their study and percent cover in our study), both suggested a negative effect on vascular plants where soil $\mathrm{pH}$ values are either too high or too low. Near the Ekati Diamond Mine, 
the optimum soil $\mathrm{pH}$ for vascular plants appears to be 4.5 to 6 . Beyond this soil $\mathrm{pH}$ range, the percent cover of vascular plants decreases, especially at higher $\mathrm{pH}$ values nearer to the road associated with road dust. Additionally, both studies indicated that lichen increases as soil $\mathrm{pH}$ decreases from 9 to 4 .

In terms of road dust impacts on soil $\mathrm{pH}$ and thus vegetation distribution, our results also agreed well with previous studies [29] [30]. For example, Myers-Smith et al. [29] reported a statistically significant logarithmic relationship between the distance from the 577-km-long Dalton Highway in Alaska and the soil pH out to 1 $\mathrm{km}$ from the road, similar to our finding. They also reported that plots adjacent to the road had significantly higher graminoid and cloudberry (Rubus chamaemorus) biomass, but less moss, evergreen shrub, lichen, and for b biomass. Our results showed different impacts on specific species, which is understandable given that the dominant plant functional types in between their study area and ours were somewhat different. Nevertheless, the reduction of lichen due to road dust was observed by both studies.

\subsection{Interpretation of Impact Assessment}

Given some of the potential uncertainties in the measurement of dust on leaves, soil $\mathrm{pH}$, and percent cover of vegetation, the results are an index of the potential effects of mine related dust on caribou forage and should be interpreted with caution. Conclusions drawn from a single parameter are less reliable. Instead, the inference should rely on the convergence of results derived from several parameters.

For example, our results indicate the zone of dust on leaves for the Misery Haul Road was about $1 \mathrm{~km}$. Dustfall monitoring results also show an increase in dust deposition up to $1 \mathrm{~km}$ [23]. A significant increase in soil $\mathrm{pH}$ from the Misery Haul Road occurred within 1 to $1.5 \mathrm{~km}$. Lichen coverage was also reduced within $1 \mathrm{~km}$ of the reduction from the Misery Haul Road. Integrating all these results together, we may conclude with confidence that the zone of affected forage (ZOAF) is about $1 \mathrm{~km}$ from the Misery Haul Road.

Our results are comparable with several regional scale landscape studies that reporting that caribou reduced the use of areas within $5 \mathrm{~km}$ from infrastructure and human activity [31]. In contrast, the $14 \mathrm{~km} \mathrm{ZOI} \mathrm{around} \mathrm{the} \mathrm{Ekati-Diavik}$ mining complex identified by [14] appears to be much larger that the ZOAF observed in this study. On the other hand, we emphasize that this study deals only with the zone of disturbed vegetation, and that of the coarse particulate matter (i.e. TSP- $\mathrm{PM}_{2.5}$ ). The zones of noise, visibility of mining, and $\mathrm{PM}_{2.5}$ could potentially reach further and represent important areas to focus future research in order to further refine our understanding of their individual and combined contributions to the extent and intensity of ZOI.

\section{Conclusions}

On the basis of two years of field data and laboratory analyses conducted on samples collected from the Ekati Diamond Mine in the Bathurst caribou range in Canada's Arctic, we draw the following conclusions. 
- Precision GPS measurements show the area surrounding the Ekati Diamond Mine is a gently rolling topographic landscape, with a range in elevation from valley to peak of $<40 \mathrm{~m}$ for all transects, with a hill or two approximately every $1 \mathrm{~km}$ along a transect.

- Dwarf shrub is the predominant land cover class across the study area, accounting for $81 \%$ coverage of all sites, followed by esker (5\%), and the low-high shrub and tussock classes ( $4 \%$ each).

- The average amount of dust measured on dwarf birch leaves collected from sites at $0-10,>10-100,>100-500,>500-1000$, and $>1000-1500 \mathrm{~m}$ from the Misery Haul Road was 8.8, 6.1, 4.2, 2.6, and 1.1 times than that from $>1.5 \mathrm{~km}$, respectively. These results indicated that the zone of raised dust on leaves was about $1 \mathrm{~km}$ from the Misery Haul Road.

- Road dust increased soil pH logarithmically, from about 4.5 at $1-1.5 \mathrm{~km}$ distance to about 9 at the roadside of the Misery Haul Road.

- The optimum soil pH for vascular plants is around $4.5-6$. The increase in soil $\mathrm{pH}$ values $>6$ within $10 \mathrm{~m}$ of the Misery Haul Road reduced vascular percent cover. An increase of dust on leaves in the zone may further contribute to this reduction.

- Lower soil pH (to about 4) favors lichen, which corresponds to a reduction in lichen cover that is observed within $\sim 1 \mathrm{~km}$ of the Misery Haul Road.

- These distance related trends in dust deposition rate, the amount of dust on leaves, the soil $\mathrm{pH}$ values, and the vegetation percent covers were not observed for sites on the transect from a rarely used spur road outside the Misery Camp.

Overall, these results suggest that the ZOAF from the Misery Haul Road is about $1 \mathrm{~km}$. On the other hand, no such a zone exists for the rarely used spur road outside the Misery Camp, indicating the ZOAF is subject to road use. Further investigation is needed for all other mining roads to fully quantify the ZOAF of the Ekati Diamond Mine within the Bathurst caribou summer range.

Finally, our results are comparable with the ZOI estimates of $1-5 \mathrm{~km}$ [31], but much less than the $14 \mathrm{~km}$ of ZOI around the Ekati-Diavik mining complex identified by [14]. Investigation of other mechanisms (e.g., the zones of noise, visibility of mining, and $\mathrm{PM}_{2.5}$ ) is essential to further refine our understanding of $\mathrm{ZOI}$.

\section{Acknowledgements}

The study was funded by the Northwest Territories Cumulative Impact Monitoring Program (NWT CIMP) and Natural Resources Canada. Dominion Diamond Ekati Corporation (DDEC) provided logistic supports, including travel, accommodation, laboratory facility for measuring soil $\mathrm{pH}$ and dust on leaves, and safety training. Wildlife technicians from DDEC (Matt Hoover, Cody Drygeese, Jeff Mantla, and Misty Sinclair) assisted us in the field surveys. Three co-op students (Charlotte Kelly of Carleton University, Anumeet Garchaand Holden Ciufo of University of Waterloo) participated the fieldwork.

\section{References}

[1] Boulanger, J., Gunn, A., Adamczewski, J. and Croft, B. (2011) A Data-Driven Model 
to Explore the Decline of the Bathurst Caribou Herd. Journal of Wildlife Management, 75, 883-896. https://doi.org/10.1002/jwmg.108

[2] Vors, L.S. and Boyce, M.S. (2009) Global Declines of Caribou and Reindeer. Global Change Biology, 15, 2626-2633. https://doi.org/10.1111/j.1365-2486.2009.01974.x

[3] Klein, D.R., et al. (2005) Management and Conservation of Wildlife in a Changing Arctic Environment. In: Symon, C., Arris, L. and Heal, B., Eds., Arctic Climate Impact Assessment, Cambridge University Press, New York, 597-644.

[4] Russell, D.E., van de Wetering, D., White, R.G. and Gerhart, K.L. (1996) Oil and the Porcupine Caribou Herd-Can We Quantify the Impacts? Rangifer, 9, 255-257. https://doi.org/10.7557/2.16.4.1252

[5] Bergerud, A.T., Luttich, S.N. and Camps, L. (2008) The Return of Caribou to Ungava. McGill-Queen's University Press, Montreal.

[6] McBean, G.A., Alekseev, G., Chen, D., Forland, E., Fyfe, J., Groisman, P.Y., King, R., Melling, H., Vose, R. and Whitfield, P.H. (2005) Arctic Climate: Past and present. In: Humfrey, M., Ed., Arctic Climate Impact Assessment, Cambridge University Press, Cambridge, 21-60.

[7] Chen, W., Russell, D.E., Gunn, A., Croft, B., Chen, W.R., Fernandes, R., Zhao, H., Li, J., Zhang, Y., Koehler, K., Olthof, I., Fraser, R.H., Leblanc, S.G., Henry, G.R, White, R.G. and Finandstad, G.L. (2013) Monitoring Habitat Condition Changes during Winter and Pre-Calving Migration for Bathurst Caribou in Northern Canada. Biodiversity, 14, 36-44. https://doi.org/10.1080/14888386.2012.705110

[8] Chen, W., White, L., Adamczewski, J.Z., Croft, B., Garner, K., Pellissey, J.S., Clark, K., Olthof, I., Latifovic, R. and Finstad, G.L. (2014) Assessing the Impacts of Summer Range on Bathurst Caribou's Productivity and Abundance Since 1985. Natural Resources, 5, 130-145. https://doi.org/10.4236/nr.2014.54014

[9] Witter, L.A., Johnson, C.J., Croft, B., Gunn, A. and Gillingham, M.P. (2012) Behavioural Trade-Offs in Response to External Stimuli: Time Allocation of an Arctic Ungulate during Varying Intensities of Harassment by Parasitic Flies. Journal of Animal Ecology, 81, 284-295.

[10] Culler, L.E., Ayres, M.P. and Virginia, R.A. (2015) In a Warmer Arctic, Mosquitoes Avoid Increased Mortality from Predators by Growing Faster. Proceedings of the Royal Society B, 282, 20151549. https://doi.org/10.1098/rspb.2015.1549

[11] Silke, R. (2009) The Operational History of Mines in the Northwest Territories, Canada. Northwest Territories Geoscience Office, Government of Northwest Territories, Yellowknife.

[12] Braden, W. (2016) GahchoKue Cuts the Ribbon. Mining North Magazine. www.miningnewsnorth.com

[13] Mackenzie, R., Dryneck, P., Pea, B., Dryneck, J., Quitte, W., Football, B., Judas, R., Smallgeese, J., Judas, J. and Kodzin, J. (2013) Cumulative Impacts on the Bathurst Caribou Herd: A Tłıcho. Traditional Knowledge Study, Research and Monitoring Program, Tłıçho, Government.

[14] Boulanger, J., Poole, K.G., Gunn, A. and Wierzchowski, J. (2012) Estimating the Zone of Influence of Industrial Developments on Wildlife: A Migratory Caribou Rangifer tarandus groenlandicus and Diamond Mine Case Study. Wildlife Biology, 18, 164-179. https://doi.org/10.2981/11-045

[15] WHO Regional Office for Europe (2000) Chapter 7.3 Particulate Matter, Air Quality Guidelines. 2nd Edition, Copenhagen.

[16] ERM (2015) Ekati Diamond Mine: 2014 Air Quality Monitoring Program. Northwest Territories, Yellowknife.

[17] Gunn, A., D’Hont, A., Williams, J. and Boulanger, J. (2013) Satellite Collaring in the 
Bathurst Herd of Barren-Ground Caribou 1996-2005. Manuscript Report No. 225, Environment and Natural Resources, Yellowknife.

[18] Chen, W., Li, J., Zhang, Y., Zhou, F., Koehler, K., Leblanc, S., Fraser, R., Olthof, I., Zhang, Y. and Wang, J. (2009) Relating Biomass and Leaf Area Index to Non-Destructive Measurements for Monitoring Changes in Arctic Vegetation. Arctic, 62, 281-294. https://doi.org/10.14430/arctic148

[19] Chen, Z., Chen, W., Leblanc, S.G. and Henry, G. (2010) Digital Photograph Analysis for Measuring Percent Plant Cover in the Arctic. Arctic, 63, 315-326. https://doi.org/10.14430/arctic1495

[20] Leblanc, S.G., Chen, W., Maloney, M., Humphrey, E. and Elliot, C. (2014) NDVI Digital Camera for Monitoring Arctic Vegetation. Proceedings of the International Geoscience and Remote Sensing Symposium, 13-18 July 2014, Quebec City. https://www.researchgate.net/publication/264193178_NDVI_DIGITAL_CAMERA_ FOR_MONITORING_ARCTIC_VEGETATION

[21] Grunsky, E.C., Drew, L.J., Woodruff, L.G., Friske, P.W.B. and Sutphin, D.M. (2013) Statistical Variability of the Geochemistry and Mineralogy of Soils in the Maritime Provinces of Canada and Part of the Northeast United States, Geochemistry: Exploration, Environment, Analysis, 13, 249. https://doi.org/10.1144/geochem2012-138

[22] Gould, W.A. and Walker, M.D. (1999) Plant Communities and Landscape Diversity along a Canadian Arctic River. Journal of Vegetation Science, 10, 537-548. https://doi.org/10.2307/3237188

[23] Blatt, H. and Tracy, R.J. (1997) Petrology. 2nd Edition, Freeman, New York.

[24] Dabek-Zlotorzynska, E., Dann, T.F., Martinelango, P.K., Celo, V., Brook, J.R., Mathieu, D., Ding, L. and Austin, C.C. (2011) Canadian National Air Pollution Surveillance (NAPS) $\mathrm{PM}_{2.5}$ Speciation Program: Methodology and $\mathrm{PM}_{2.5}$ Chemical Composition for the Years 2003-2008. Atmospheric Environment, 45, 673-686. https://doi.org/10.1016/j.atmosenv.2010.10.024

[25] Guo, H., Xu, L., Bougiatioti, A., Cerully, K.M., Capps, S.L., Hite, J.J.R., Carlton, A.G., Lee, S.H., Bergin, M.H., Ng, N.L., Nenes, A. and Weber, R.J. (2105) Fine-Particle Water and $\mathrm{pH}$ in the Southeastern United States. Atmospheric Chemistry and Physics, 15, 5211-5228. https://doi.org/10.5194/acp-15-5211-2015

[26] Conti, M.E. and Cecchetti, G. (2001). Biological Monitoring: Lichens as Bioindicators of Air Pollution Assessment-A Review. Environmental Pollution, 114, 471 492. https://doi.org/10.1016/S0269-7491(00)00224-4

[27] Farmer, A.M. (1993) The Effects of Dust on Vegetation-A Review, Environmental Pollution, 79, 63-75. https://doi.org/10.1016/0269-7491(93)90179-R

[28] Brennand, T.A. (2000) Deglacial Meltwater Drainage and Glaciodynamics: Inferences from Laurentide Eskers, Canada. Geomorphology, 32, 263-293. https://doi.org/10.1016/S0169-555X(99)00100-2

[29] Myers-Smith, I.H., Arnesen, B.K., Thomson, R.M. and Chapin III, F.S. (2006) Cumulative Impacts on Alaskan Arctic Tundra of a Quarter Century of Road Dust. Ecoscience, 13, 503-510. https://doi.org/10.2980/1195-6860(2006)13[503:CIOAAT]2.0.CO;2

[30] Walker, D.A. and Everett, K.R. (1987) Road Dust and Its Environmental Impact on Alaskan Taiga and Tundra. Arctic and Alpine Research, 19, 479-489. https://doi.org/10.2307/1551414

[31] Vistnes, I. and Nellemann, C. (2008) The Matter of Spatial and Temporal Scales: A Review of Reindeer and Caribou Response to Human Activity. Polar Biology, 31, 399-407. https://doi.org/10.1007/s00300-007-0377-9 
Submit or recommend next manuscript to SCIRP and we will provide best service for you:

Accepting pre-submission inquiries through Email, Facebook, LinkedIn, Twitter, etc. A wide selection of journals (inclusive of 9 subjects, more than 200 journals)

Providing 24-hour high-quality service

User-friendly online submission system

Fair and swift peer-review system

Efficient typesetting and proofreading procedure

Display of the result of downloads and visits, as well as the number of cited articles Maximum dissemination of your research work

Submit your manuscript at: http://papersubmission.scirp.org/

Or contact jep@scirp.org 